\section{Фелікс Левітас,}

завідувач кафедри

історичної і громадянської освіти

Інституту післядипломної освіти

Київського університету

імені Бориса Грінченка,

доктор історичних наук, професор,

київ, Україна

\author{
Felix Levitas, \\ Head of the Departament \\ of Historical and Civic Education, \\ Institute of Postgraduate Education, \\ Borys Grichenko Kyiv University, \\ Doctor of History, Professor, \\ Kyiv, Ukraine
}

e-mail: f.levitas@kubg.edu.ua
ORCID iD:0000-0003-1049-3905

Шаміль Рамазанов,

дочент кафедри історії

Начіонального технічного університету

України «Київський політехнічний інститут

імені Ігоря Сікорського»,

кандидат історичних наук, дочент,

Київ, Україна

e-mail:naukoved@ukr.net

ORCID iD: 0000-0001-8603-0152

\section{Shamil Ramazanov,}

Associate Professor

of the Deparment of History,

National Technical University of Ukraine

"Igor Sikorsky Kyiv Polytechnic Institute",

PhD in History, Associate Professor,

Kyiv, Ukraine

\title{
Переддень і початок німецько-радянської війни в дослідженнях істориків зарубіжжя
}

Стаття присвячена ключовим питанням передодня і початку першого періоду німецько-радянської війни, що знайшли відображення в зарубіжній історіографії. Автори здійснили історичну репрезентацію найвідоміших праць зарубіжних науковців, чиї напрацювання є вагомим аргументом для сучасного українського дискурсу. Їхні оцінки й наведені факти й аргументи створюють широку панораму мілітарних подій, руйнують старі та нові міфи про минулу війну. Зокрема, щодо політичних маневрів СРСР і Німеччини напередодні війни, стратегічних планів РСЧА та вермахту, перебігу бойових дій на радянсько-німецькому фронті в червні - грудні 1941 року.

Ключові слова: зарубіжна історіографія, німечько-радянська війна, РСчА, вермахт, «блискавична війна», план «Барбаросса», Голокост.

\section{The Run-up and the Beginning of the German-Soviet War in the Research of Foreign Scholars}

The article is dedicated to the key issues of the run-up and beginning of the first period of the GermanSoviet war, which are reflected in foreign historiography. The authors of the publication tried historically reconstruct the events that preceded Nazi Germany's attack on the USSR, the military confrontation on the Soviet-German battlefield from June 22 to December 1941 based on the most famous works of researchers from neighboring countries and beyond.

The publication attempts to cover a wide range of problems: secret diplomacy, political maneuvers of the USSR and Germany in advance of the war, strategic plans of the Workers' and Peasants' Red Army and the Wehrmacht, the course of military operations on the Eastern Front in the summer and winter of 1941. The authors of the publication mainly focus on documents and materials belonging to direct participants of the events, well-known scholars and politicians. The facts and analysis of historical events presented by them cannot remain outside the scientific controversy. The geopolitical plans of the Nazis, who posed a threat to the entire world civilization, seem impressive.

The article refutes most of the assessments and key conclusions from the times of Soviet historiography. Important historical sources included in the scientific discourse deny the conceptual issues of the Soviet historical narrative about the nature of international relations on the run-up of the war and the initial period of the war with Nazi Germany. The authors explain their critical attitude to the publications 
of the post-Soviet era, which, first, do not pass the source test, and second, do not meet the principles of humanism, democracy and tolerance, which are inherent in the ideas of the 21st century.

To obtain unbiased results and conclusions, the authors of the publication relied on various methods of scientific research: content analysis, synthesis, historical-comparative, historical-chronological, critical and comparative analyses.

The authors believe that this publication is not only of scientific and cognitive interest, but provides a deep understanding of the lessons of the past war, which are important for the current security of the Ukrainian state and formation of patriotic consciousness of society, unbiased evolvement of its historical memory.

The presented results of research in foreign historiography are a strong argument for modern Ukrainian discourse.

The main visions of the authors meet the consolidation of the current scientific trend of Ukraine glorification of the significant role of the Ukrainian people in the victory over Nazi.

Key words: foreign historiography, German-Soviet war, Workers' and Peasants' Red Army, Wehrmacht, "blitzkrieg", operati+on Barbarossa, Holocaust.

$\Pi$ очатку німецько-радянській війні в різних країнах світу присвячено тисячі наукових і науково-популярних праць. Загалом дослідники точно визначили пульс історичних подій і описали найзначніші битви. Але ще багато подій минулої війни з різних мотивів залишаються в тіні наукових пошуків. Американський експерт з військової історії Д. Гланц визначає причини такої ситуації: 1) недостатньо вивчена архівна база через закритість багатьох джерел, які $є$ не завжди бажаними, адже можуть негативно впливати на національну психологію, порушувати репутацію країни та армії; 2) у деяких країнах (приміром, у Росії) дотепер існує обмеження і навіть цензура на використання певних категорій архівних документів та їх інтерпретацію (Гланц Д., 2009. С. 402).

Для українського народу, який зазнав величезних втрат в боротьбі з нацизмом, зазначена проблема залишається актуальною і злободенною. Вона $\epsilon$ повчальним історичним уроком, що видається важливим для сучасної безпеки Української держави.

Радянська історіографія створила масштабний історичний наратив про Велику Вітчизняну війну. Агітаційно-пропагандистський характер радянської історичної науки об'єднав в собі як ідеологічні міфи, так і правдиві факти, чим створив значні труднощі для науковців в їхніх прагненнях і пошуках істини. Спроба «механічно» переглянути трагічні сторінки минулої війни, до якої вдалися окремі сучасні дослідники, намагаючись ліквідувати «білі плями» історії, ще більше заплутали ситуацію і народили новий історичний міф. Невипадково ізраїльський історик Г. Городецький писав: «Колишні “білі плями” сьогодні заповнюються набором брехні, тенденційними зібраннями фактів, які пропонують громадськості брати за істину...» (Городецький Г., 1995. С. 3). А канадсько-український історик С. Єкельчик значно глибше розуміє проблему, що виникла в «битвах» за історію, акцентуючи увагу на тому, що «ні радянська-пострадянська, ні націонал-радикальна версії історії війни не можуть однозначно претендувати на історичну правду чи виключність, адже жодна 3 них не відповідає гуманістичним традиціям XXI століття, принципам свободи, демократії і толерантності...» (Єкельчик С., 2020. С. 28-29).

На альтернативу до багатьох історичних досліджень претендують спогади безпосереднього учасника подій, нацистського дипломата Г. Хільгера. Він був переконаний, що Сталін мав якийсь таємний план, щоб напасти зненацька на Німеччину. Підписаний пакт Молотова Ріббентропа вважав початком підготовки для такого нападу. Хільгер доводив, що Сталін все прорахував: війна Німеччини 3 Польщею залучить на бік останньої іï стратегічних союзників - Англію та Францію. А коли всі воюючі країни будуть послаблені, кремлівський володар кине на чашу терезів всю міць Радянського Союзу. Цікаво, що міркування нацистського дипломата як базова наукова гіпотеза були підхоплені цілою групою істориків в різних країнах (Откровения и признания..., 2000. С. 70-71).

Мета публікації - показати основні візії зарубіжних науковців щодо переддня і початку німецько-радянської війни, акцентувати увагу на контроверсійних версіях сучасної історичної думки. Окрім загальнонаукових методів аналізу і синтезу, для оцінок подій і фактів, викладених в сучасній історіографії, були використані історико-порівняльний, компаративний, критичний методи.

Спроба зміни історичної парадигми вперше потужно відбулась в Англії під впливом викладу «таємниць» Другої світової війни колишнім радянським розвідником (талановитим публіцистом В. Суворовим - С.В. Резуном). Ця подія спонукала науковців панорамно повернутися до оцінки переддня і початку німецько-радянської війни.

Концепція В .Суворова, що знайшла чимало симпатиків та послідовників в Україні та зарубіжжі, грунтувалась на двох базових висновках: 
1) Гітлер на кілька тижнів випередив 3 першим ударом СРСР, який сам готувався напасти на Німеччину; 2) війна Німеччини з Радянським Союзом носила здебільшого превентивний характер і була направлена в цілому проти існуючої на сході Європи політичної системи.

Але підтвердження В. Суворова та його послідовників не проходять джерельної перевірки. Адже концентрація німецьких військ на кордоні, на теренах Польщі, почалась з кінця 1939 р., рішення про напад на СРСР було ухвалено в липні 1940 р., план «Барбаросса» в цілому було затверджено в грудні 1940 р., а окремі деталі плану ще доопрацьовувалися навесні 1941 року.

Як стверджує історик М. Мельтюхов, радянське військове командування в глибокій таємниці здійснювало розробку плану війни з Німеччиною та іiї можливими союзниками. Введення до наукового обігу документів радянського військового планування показало, що Німеччина продовжувала розглядатися як вірогідний противник № 1, попри імітацію зближення 3 нею (Мельтюхов М., 2000. С. 273). Уважно аналізуючи історичну версію, викладену в праці М. Мельтюхова, український дослідник М. Попович продовжував дотримуватися власної позиції: «...жодного політичного рішення про напад на Німеччину, жодної переорієнтації на війну проти країн Пакту не було і не могло бути». На підтримку своєї думки М. Попович посилається на епізод, коли нарком С. Тимошенко і начальник Генерального штабу Г. Жуков, за власними рефлексіями, після промови Сталіна 5 травня 1941 року перед випускниками військових академій, запропонували упереджуваний удар по військам вермахту, зосереджених на теренах Польщі. Кремлівський диктатор вилаяв військових і відкинув їхній проєкт. Так була похована ідея про упереджуваний удар. А кремлівський тиран продовжував «умиротворяти» Адольфа Гітлера (Попович М., 2005. С . 457-459).

Британські історики Митчем С. та Мюллер Дж. наголошують на тому, що у березні 1941 року Гітлер особисто розробив нову концепцію ведення війни на Сході. На його думку, це мала бути жорстока битва, спрямована на абсолютне й безжальне знищення противника. А фельдмаршал В. Кейтель своїми наказами ще до початку «бліцкригу» доніс ідею фюрера до військових (Митчем С., Мюллер Дж., 1995. С. 24).

Сталінський Радянський Союз зовсім не був «голубом миру», як його змальовувала кремлівська пропаганда 1939-1940 року. Він активно здійснював військові анексії в Європі, не звертаючи уваги на політичні наслідки подій і порушення норм міжнародного права. Але, як свідчать відомі генерали вермахту, на 1941 рік Червона Армія перебувала в стані реорганізації і планів раптового нападу на Німеччину не мала (Левітас $\Phi$.,
2002. С. 96-99). Важливими для сучасних наукових оцінок $є$ факти, наведені німецьким істориком Г. Якобсеном. Автор стверджує, що влітку 1941 року після початку плану «Барбаросса» спеціальні німецькі команди вели розшук радянських штабних документів про підготовку нападу РСЧА на Німеччину, але таких документів виявлено не було (Якобсен Г., 2005. С. 154-232).

План «Барбаросса» й додатки до нього - план «Ост» (Схід), «Зелена папка Г. Геринга» та інші секретні документи Третього Рейху - свідчать про тотальний характер війни на знищення, яку готувала нацистська верхівка, передбачаючи не лише колонізацію територій на Сході (перш за все ії цікавила Україна, - Ф.Л., Ш.Р.), а й масштабні етнічні чистки, що мали звільнити для майбутніх німецьких господарів «життєвий простір». I Голокост, власне, був лише жахливою прелюдією до загального нацистського геноциду. Британський історик М. Гейстингс зазначає, що від часів революції 1917 року населення Радянського Союзу зазнало жахів громадянської війни, голоду, тиранії, загальної несправедливості, однак реалізація планів «Барбаросса», «Ост» тощо являла собою цілковиту гуманітарну катастрофу для суспільства, якому навала загрожувала тотальним винищенням (Гейстингс М., 2019. С. 184-185). Якщо порівняти нацистський окупаційний режим Західної і Східної Європи, то наочно прослідковується його відмінність. На Заході нацисти претендували здебільшого на території та економічні ресурси захоплених країн, на Сході, особливо на теренах СРСР і Польщі, вони застосовували поетапно масовий геноцид. Спочатку це були євреї, роми, комуністи і радянські активісти. Потім - всі інші. Таємна «Програма Т4», яка використовувалась в Німеччині в 1939-1941 рр., мала охопити расово неповноцінних людей, а 3 початком німецькорадянської війни іiі було перенесено на захоплені гітлерівцями території (Хоус Дж., 2020. С. 206-207).

Старий заклик хрестоносців "Drang hach Osten” («На Схід») заповідав теперішнім нащадкам тевтонців вбивство мільйонів невійськових, представників різних етносів: поляків, українців, євреїв, білорусів, кашубів тощо. Німецький історик X. Хене наводить безкомпромісний документ, підготовлений рейхсфюрером СС Г. Гіммлером ще в травні 1940 року: «Такі етнічні поняття, як українці, горали, лемки в нашій зоні повинні повністю зникнути...» (Хене Х., 2004. С. 236-237). Колега Х. Хене, німецький історик Вернер Піхт, констатує, що на теренах Радянського Союзу супротивник був таврований як людина нижчої раси, до якої дозволено будь-які насильницькі дії. Населення захоплених областей, спочатку ладне вітати німців як визволителів, було перетворено на рабів. Це активізувало піднесення партизанського руху. За лінією фронту підрозділи СС влаштовували єврейські 
погроми. Нелюдське ставлення до військовополонених створило такі умови, коли противник відчайдушно воював до останнього патрону (Выводы побежденных..., 1998. С. 63). День 22 червня 1941 року остаточно змінив характер Другої світової війни. Боротьба проти нацистів здобувала з боку всіх поневолених гітлерівцями народів визвольний і справедливий характер. Перемога об’єднаних націй над Гітлером і його союзниками постала у порядку денному, адже перемога «держав Осі» означала 6 кінець європейської цивілізації, занурення світу в «простір смерті», $з$ якого вибратися було 6 вже неможливо. Враховуючи всі політичні, ідеологічні та військові аспекти Другої світової війни, М. Попович писав: «То була дійсно Вітчизняна війна для всіх народів з різними вітчизнами, які опиралися прагненню нацистів перетворити їх на гній для “вищої раси”. То була війна за визволення від кошмару, який раптом став реальністю, на величезних просторах цивілізованого світу...» (Попович М., 2005. С. 497).

Про те, що думка М. Поповича має сенс, свідчить і висновок відомого американського політика М. Олбрайт: радянські солдати йшли в бій не за Сталіна і більшовизм, а вели боротьбу на захист вітчизни проти фашистської навали (Олбрайт М., Вудворт Б., 2019. С. 122).

Йосип Сталін та його кремлівське оточення несуть пряму відповідальність за трагедію 1941 року. За роки репресій три чверті всього вищого командного складу було репресовано. Перші удари нацистів по теренах СРСР здебільшого для військ західних військових округів виявилися несподіванками. Оборонні споруди на «лінії Молотова» і «лінії Сталіна» до реальної відсічі ворогу підготовлені не були. Населення СРСР психологічно не було готове до нападу нацистів, адже радянська пропаганда запевняла суспільство у непорушності радянсько-німецьких договорів 23 серпня і 28 вересня 1939 року. Уже згаданий нами німецький дипломат Г. Хільгер, власне, підтверджує жахливу істину: коли генерали Третього Рейху вносили останні зміни в план «Барбаросса», за яким «німецькі збройні сили повинні бути готові... під час швидкої кампанії знищити Радянську Росію, в Москві того самого моменту кілька людей було засуджено на довгі терміни покарання у виправно-трудових таборах за розповсюдження чуток про неминучість німецько-радянської війни...» (Хильгер Г., Мейер А., 2008. С. 393).

Документи передодня війни фіксують у багатьох частинах і підрозділах західних військових округів факти порушення присяги і військової дисципліни. За два тижні до початку німецької навали на ім'я наркома внутрішніх справ Л. Берії було направлено доповідну записку з грифом «Цілком таємно», що сповіщала про стан дисципліни у військових частинах Київського військового округу. У записці наголошувалось на фактах пияцтва, самовільного залишення частин, дезертирства та антирадянських настроїв, які мали місце серед червоноармійців округу (Радянські органи державної безпеки у 1939 червні 1941 р., 2009. С. 1150-1151). Тривожних фактів вистачало й у військах Прибалтійського військового округу. Приміром, напередодні війни Іван Черняхівський очолив 28 танкову дивізію, що дислокувалась у Литві. Щоб перевірити ії боєздатність, комдив без попередження особового складу оголосив навчальну тривогу. Але частина командного офіцерського корпусу вибула з місць оповіщення, а новопризначені офіцери про свої адреси не повідомили. У результаті за сигналом тривоги молоді командири на місця служби не з'явилися. Танкові підрозділи й боєкомплекти до них знаходились в різних місцях. Кожний полк намагався вкластися в норматив часу і якнайшвидше отримати боєприпаси. Виникли хаос, сум'яття і штовханина, що зводило нанівець бойову готовність дивізії. Під час розгортання танкових полків дивізії виявилось, що радисти переважно не володіють засобами зв'язку і тому не в змозі координувати свої дії (Шарипов А., 1978. С. 51-52).

Першими удар прийняли прикордонники. За планом «Барбаросса» вермахт мав подолати прикордонні перешкоди за 20-30 хвилин. Вважалось, що застави 3 особовим складом 50-70 чоловік, маючи легке стрілецьке озброєння, не зможуть протистояти німецьким військам, підтримуваним авіацією, танками й артилерією. Численні історичні документи свідчать, що в перші години війни прикордонні застави Західних військових округів вели запеклу боротьбу з ворогом. Жодна з 485 застав не стали легкою здобиччю нацистів. Особливо запеклі бої тривали в Україні на ділянках Любомирського, Володимир-Волинського, Рава-Руського, Перемишльського, Черновицького прикордонних загонів. Прикордонники не лише стримували ворожі частини, а й успішно контратакували, відкидаючи німців за державний кордон, як це сталося в районі п. Перемишль (Муковський I.T., Лисенко О.Є., 1996. С. 32). Аналіз журналів бойових дій на Південно-Західному фронті підтверджує, що основні сили прикордонників почали відхід на з'єднання з частинами Червоної Армії не раніше 23 червня 1941 року (о 23.30), утримуючи весь шалений тиск німецького угрупування «Південь». Прикордонники, ті, хто залишилися живими, відійшли зі своїх позицій тільки тоді, коли всі засоби оборони кордону були вичерпані (Пограничные войска СССР в Великой Отечественной войне..., 1976. С. 173-180). Згодом у бій вступили регулярні частини Червоної Армії.

Панорамний оглядподій, які відбувалися в перший тиждень війни, дає зрозуміти, що на багатьох 
ділянках радянсько-німецького фронту вони розвивалися за різними сценаріями. Найбільш вражаючих успіхів вермахт здобув в Білорусі, завдавши важкої поразки військам Західного військового округу. До кінця червня німці загнали в «котли» в районі Білостока і Мінська радянські війська й захопили білоруську столицю. В історичній літературі тоталітарної і пострадянської доби утворилася необ'єктивна традиція в трагедії Західного фронту звинувачувати керівництво фронту на чолі з Героєм Радянського Союзу Д. Павловим. Насправді, до перших залпів війни командувач Західного військового округу точно виконував всі вказівки Кремля, особистої ініціативи не виявляв, але руку на пульсі подій тримав. Хоробрості Д. Павлову можна було не позичати, але його низький теоретичний і військово-стратегічний рівень виявився під час штабних ігор 1940-1941 років. Утім на той час постать комокругу повністю влаштовувала Сталіна. I вже 23 червня за наказом Д. Павлова війська намагалися організувати контрудар по флангам групи «Центр», але удар «захлинувся» внаслідок того, що закінчилось паливо, боєприпаси, а в небі повністю панувала німецька авіація (Шапталов Б., 2002. С. 91-92). Не можна обійти стороною і героїчну оборону Мінська 100-ю стрілецькою дивізією генерал-майора I. Русіянова. Зайнявши оборону в 10-15 км від столиці, дивізія не лише вдало стримувала наступ німецьких танків, але й успішно контратакувала їх і відступила тільки з підходом підкріплень до німців. Власне, результативні бої дивізії Русіянова показали, що за умов ефективного керівництва військами можлива успішна відсіч ворога. Але це був лише епізод (Шапталов Б., 2002. С. 94). За наказом Йосипа Сталіна відбулась заміна керівництва на Західному фронті, а генерала Д. Павлова разом з іншими керівниками фронту стратили. Об’єктивно розмірковуючи над трагедією оточення і поразки військ Західного військового округу, англійський військовий історик А. Кларк стверджує, що у Д. Павлова в тій ситуації, що склалась на 22 червня, майже не було шансів успішно протистояти німецькій групі «Центр», адже, маючи у складі фронту переважно стрілецькі дивізії, він не міг довго утримувати оборону одразу проти трьох німецьких танкових груп Гьопнера, Гота і Гудеріана, у складі яких було майже 80 \% від загальної кількості німецьких танків (Кларк А., 2002. С. 55).

Події, що відбувалися на Південно-Західному фронті, розвивалися за іншим сценарієм, ніж на Західному напрямку. Власне тому і вимагають неупередженого огляду й коментарів, якщо враховувати безліч різноманітних контроверсійних оцінок. Російському історику В. Рунову, який присвятив чимало вагомих військових праць подіям 1941 р. в Україні, належить ряд думок і висновків, що мають переконати суспільство в наступному:
1) від першого наступу німців керівництво Південно-Західного фронту розгубилось, діяло нерішуче i, власне, втратило керівництво військами; 2) генерал Г. Жуков, якого Сталін направив на Південно-Західний фронт, намагався стабілізувати ситуацію і утримував керівництво фронту від непродуманих дій; 3 ) задум німецького командування в перші дні наступу було не лише виконано, але на окремих ділянках і перевиконано (Рунов В., 2011. С. 136-137; Рунов В., 2010. С. 126-127). Насправді висновки російського історика не витримують джерельної перевірки й тому не відображають реальні події. По-перше, бойове розгортання військ КВО М. Кирпонос почав ще за кілька днів до початку німецького вторгнення. По-друге, від «раптового» удару армії Південно-Західного фронту «відійшли» дуже швидко й стали чинити німцям відчайдушний опір. Про це нотує в своїх щоденниках генералфельд-маршал Ф. Гальдер: «23 червня. Найбільш складною я вважаю обстановку на фронті групи армій “Південь", які, на жаль, несуть значні втрати. У противника застосовано проти групи "Південь" тверде й енергетичне керівництво...» (Гальдер Ф., 2004. С. 41). 3 оцінками Ф. Гальдера суголосні думки гітлерівського генерала Г. Гота. Власне, наголошуючи на загальному успіху вермахту на Центральному напрямку, генерал констатував важке становище групи «Південь», яке зазнавало постійних контрударів радянських військ (Гот Г., Гудеріан Г., 1999. С. 76).

Трагічні події на Південно-Західному фронті якраз почалися після втручання Г. Жукова в справи фронту. Вірно оцінивши ситуацію, яка склалась в перші дві доби від початку війни, М. Кирпонос, стримуючи на кордоні шалений тиск німців, вирішив дочекатися підходу всіх механізованих корпусів, щоб завдати нищівного удару по німецькій групі «Південь». Значуща перевага в танках - 4200 радянських всіх видів, включно зі значною кількістю КВ і Т-34 проти 900 панцирників легких і середніх конструкцій армій Рунштедта - відкривала можливості не лише завдати ворогу втрат, а принципово змінити ситуацію на всьому радянсько-німецькому фронті. Г. Жуков зажадав від штабу фронту негайного виконання Директиви № 3, підписаної Сталіним. Директива передбачала: терміново перейти в рішучий наступ проти німецьких військ, стрімко вийти на державний кордон СРСР і перенести бойові дії на ворожу територію. Штаб фронту й особисто М. Кирпонос добре розуміли негативні наслідки сталінського наказу, але не виконати рішення Кремля в бойовій ситуації не могли. У районі Луцьк - Рівне - Броди розпочалася найбільша танкова битва в історії Другої світової війни. Радянські механізовані корпуси, які по черзі вступали в бій часто без попередньої розвідки, потрапляли під шалений вогонь німецьких 
гармат. Стрілецькі та артилерійські підрозділи фронту ще не встигли підійти. I якщо танкістам вдавалося звільнити від ворога плацдарм, то через відсутність прикриття піхоти його доводилося залишати. Постійно відчувалась нестача боєприпасів і пального. Останнє перетворювало могутні бойові машини на непотріб. За спогадами очевидців, воїни в чорних комбінезонах знімали 3 танків озброєння та бились 3 німцями як піхотинці, а застиглі вздовж дороги могутні бойові машини залишали чи підривали. Серед молодшого і середнього офіцерського складу наочно виявилась відсутність досвіду управління танковими підрозділами в бою. У вирішальний момент танкової битви більшість молодших командирів не мала мап маршрутів, зв'язку із штабами, контактів із сусідами. Деякі підрозділи так і не зуміли вийти на бойовий рубіж. Одним із трагічних вражаючих фактів є те, що велику кількість танків, що рухалися без прикриття авіації, німці знищили з повітря (Левітас Ф., 2012. С. 102-106).

У колишній радянській i, наразі, в сучасній «охоронній» російській історіографії продовжує культивуватися міф, що танковий контрнаступ 6-ти радянських механізованих корпусів був дуже значущим, тому що майже на тиждень затримав рух військ гітлерівської Німеччини в Україні (Ванюков Д., Гнусарьков А., 2007. С. 20). Віддаючи належне героїчному подвигу танкістів Південно-Західного фронту, зауважимо, що ціна, яку заплатило радянське командування за спробу змінити стратегічну ситуацію на радянсько-німецькому фронті, була величезною і невиправданою. Історик К. Плєшаков справедливо вважає, що червневий контрудар на Півдні був одним із найбільших помилок Верховного головнокомандування за всю кампанію 1941 року. Замість того щоб зберегти найсильнішу танкову групу шляхом іï відводу й організації оборони, радянське керівництво, по суті, знищило іiі, посилаючи бойові машини в одну за іншою безглузді атаки (Плешаков К., 2006. С. 274). Значні втрати привели до того, що вже 15 липня 1941 року Ставка Верховного Головнокомандування видала директиву про розформування механізованих корпусів і розподіл броньової техніки між окремими танковими бригадами та батальйонами. Але факт залишається фактом. М. Кирпоносу вдалося відірватися від авангарду групи армій «Південь» і на третій тиждень війни закріпитися на останньому рубежі (Київському. - Ф.Л., Ш.Р.) «лінії Сталіна». 11 липня авангард німців вийшов на першу лінію оборони української столиці на р. Ірпінь, але після безперервних боїв і втрат здобути іiі не зміг. Почалась 78-денна оборона Києва.

у липні 1941 р. вермахт і СС продовжували активно просуватися радянськими теренами, але в ставці Гітлера за участю стратегів
Генерального штабу після детального аналізу боїв на Східному фронті дійшли висновку — в німецькому поступі проглядається початок кризи. Вести наступ на трьох стратегічних напрямах (Москва, Ленінград, Київ, - Ф.Л., Ш.Р.) німецькі війська вже неспроможні (Герлиц В., 2005. С. 381, 384). Водночас виникла суперечка між Гітлером та Верховним командуванням вермахту (Кейтель, Йодель) з однієї сторони і Верховним командуванням сухопутних військ (Браухич, Гальдер) з іншої 3 оперативних, тактичних, i, зрештою, стратегічних питань. Гітлер наполягав на зміні головного стратегічного напряму - зосередити всі сили на Півдні і завдати удар Україні з наступним виходом до Криму і Кавказу. Штаб сухопутних військ відстоював необхідність продовження наступу на Москву. Зрештою Гітлер переміг і нацистський «вал» розгорнувся на Південь. Англійський історик і експерт британської військової розвідки Л. Дейтон, узагальнивши значний масив різноманітної літератури, посилаючись на спогади полководців вермахту, стверджує, що рішення Гітлера мало трагічний характер, і не лише для військової кампанії 1941 року, але й катастрофічно вплинуло на весь подальший хід радянсько-німецької війни. I хоча на німецьких мапах все виглядало великою перемогою (оточення і полон 650 тисяч військ Південно-Західного фронту, які захищали Київ. - Ф.Л., Ш.Р.), час і динаміку наступу на Москву було втрачено (Дейтон Л., 2000. С. 523526).

Рішучий наступ на радянську столицю відновився тільки в кінці вересня. Ще тоді зброєю вермахту і СС були здобуті нові перемоги (оточення радянських військ під Вязьмою. - Ф.Л., Ш.Р.), але було вже вочевидь зрозуміло, що «пружина «Барбаросса» послабла, до того ж різко змінювалися природні умови - після осінніх дощів одразу настала морозна зима. Насправді скрізь посилювався опір Червоної Армії, яку німецькі стратеги давно вже вважали розбитою. Гітлерівська операція «Тайфун», що мала стати завершальним акордом плану «Барбаросса», перетворилась на пастку й катастрофу для Німеччини. Німецький генерал Блюментрітт визнає, що грудневий контрнаступ радянських військ під Москвою остаточно поховав план «Барбаросса» і всі сподівання на успіх в блискавичній війні (Роковые решения Вермахта..., 1999. С. 120-121). Об'єктивно осмислити трагічні події 1941 року і підвести підсумки авторам допомогли роздуми М. Олбрайт: «Кожна миля заглиблення німців уперед подовжувала їхні шляхи постачання, а кожний тиждень, що минав, приносив короткі дні, холодніші вітри, більше дощу, а від жовтня — й сніги. Коли розвіялася несподіванка нападу, воїни Третього Рейху вперше опинилися в справжній битві...» (Олбрайт М., Вудворт Б., 2019. С. 108). 
Важкі уроки 1941 року є важливими з позиції історичної правди й успішного майбутнього. Нашим сучасникам залишається вражатися тому, якою була сила духу суспільства, яке всупереч сталінській антигуманній системі, жахливим втратам і гіркоті поразок перших місяців війни знайшло в собі сили вистояти і перемогти. Зарубіжний досвід й історичні практики іноземних фахівців дають можливість значно розширити поле для наукового дискурсу, за допомогою важливих фактів і аргументів дати вірні та чесні відповіді на проблемні питання Другої світової війни.

\section{СПИСОК БІБЛІОГРАФІЧНИХ ПОСИЛАНЬ}

Ванюков Д., Гнусарьков А. Великая Отечественная война. М. : Мир книги, 2007. 240 с.

Вестфаль 3., Крайпе В., Блюментрит Г. и др. Роковые решения Вермахта. Ростов н/Д : Феникс, 1999. $384 \mathrm{c}$.

Гальдер Ф. Военный дневник. 22.06.1941-24.09.1942. М. : Олма-Пресс, 2004. 650 с.

Герлиц В. Германский Генеральный штаб. История и структура. 1657-1945. М. : Центрполиграф, 2005. $478 \mathrm{c.}$

Гейстингс М. І розверзлося пекло... Світ у війні 1939-1945 років. Харків : Клуб Сімейного дозвілля, 2019. $748 \mathrm{c}$.

Гланц Д. Восставшие из пепла. М. : Яуза, Эксмо, 2009. 544 с.

Городецкий Г. Миф Ледокола. Накануне войны. М. : Прогресс, Академия, 1995. 352 с.

Гот Г., Гудериан Г. Танковые операции. «Танки - вперед». Смоленск : Русич, 1999. 496 с.

Дейтон Л. Вторая мировая война: ошибки, промахи, потери. М. : Эксмо-Пресс, Эксмо-Маркет, 2000. $672 \mathrm{c}$.

Єкельчик С. Український досвід Другої світової війни. К. : Медуза, 2020. 268 с.

Кларк А. План «Барбаросса». Крушение Третьего Рейха. 1941-1945. М. : Центрполиграф, 2002. 491 с.

Левітас Ф. Напад нацистської Німеччини на СРСР очима генералів Вермахту. Сторінки воєнної історії України. 2002. Вип. 6. С. 96-99.

Левітас Ф. Друга світова війна: український вимір. К. : Наш час, 2012. 272 с.

Мельтухов М. Упущенный шанс Сталина. М. : Вече, 2000. 608 с.

Митчем С., Мюллер Дж. Командиры Третьего Рейха. Смоленск : Русич, 1995. 480 с.

Муковський І., Лисенко О. Звитяга і жертовність. Україна на фронтах Другої світової війни. К. : Книга пам’яті України, 1996. 568 с.

Олбрайт М., Вудворт Б. Фашизм: засторога. К. : Форс-Україна, 2019. 352 с.

Плешаков К. Ошибка Сталина. Первые 10 дней войны. М. : Эксмо, 2006. 416 с.

Попович М. Червоне століття. К. : АрТек, 2005. 888 с.

Радянські органи державної безпеки у 1939 - червні 1941 р. Документи ГДА СБ України / Ред. кол.: Боряк Г., Даниленко В. (від. ред)., Кокін С., Лисенко О. та ін. К. : Видавничий дім «КиєвоМогилянська Академія», 2009. 1311 с.

Рунов В. Удар по Украине. Вермахт против Красной Армии. М. : Вече, 2011. 384 с.

Рунов В. Победный парад Гитлера. Правда об Уманском побоище. М. : Яуза, Эксмо, 2010. 416 с.

Откровения и признания. Нацистская верхушка о войне «Третьего Рейха» против СССР. Секретные речи. Дневники. Воспоминания / Рудой Г. (сост). Смоленск : Русич, 2000. 640 с.

Пограничные войска СССР в Великой Отечественной войне. 1941: сборник документов и материалов / Соловьев И., Чугунов А. (сост). М. : Наука, 1976. 943 с.

Типельскирх К., Кессельринг А., Гудериан Г. и др. Итоги Второй мировой войны. Выводы побежденных. М. : Полигон. АСТ, 1998. 634 с.

Хоус Дж. Краткая история Германии. М. : Азбука-Аттикус, 2000. 256 с.

Хайнс Х. СС и орден «Мертвая голова». М. : Центрполиграф, 2004. 492 с.

Хельгер Г., Мейер А. Россия и Германия. Союзники или враги? М. : ЗАО «Центрполиграф», 2008.415 с.

Шарипов А. Черняховский. М. : Молодая гвардия, 1978. 304 с.

Якобсен Г. Вторая мировая война. Взгляд из Германии. М. : Яуза, Эксмо, 2005. 416 с.

\section{REFERENCES}

Albright, M., \& Woodward, B. (2019). Fashyzm: zastoroha [Fascism: A Warning]. Kyiv: Fors-Ukraina [in Ukrainian].

Clark, A. (2002). Plan Barbarossa: Krushenie Tretiego Reikha. 1941-1945. Moskva: Tsentrpoligraf [in Russian].

Danylenko, V. (Ed.). (2009). Radianski orhany derzhavnoi bezpeky u 1939 - chervni 1941 r. Dokumenty HDA SB Ukrainy. Kyiv: Vydavnychyi dim "Kyievo-Mohylianska Akademiia”. [in Ukrainian]. 
Deiton, L. (2000). Vtoraia mirovaia voina: oshibki, promakhi, poteri. Moskva: Eksmo-Pres, Eksmo-Market [in Russian].

Görlitz, W. (2005). History of the German General Staff, Its History and Structure 1657-1945. Moskva: Centrpoligraf [in Russian].

Görlitz, W. (2005). Germanskii Generalnyi shtab 1657-1945. Istoriia i struktura [The German General Staff, Its History and Structure 1657-1945]. Moskva: Tsentrpoligraf [in Russian].

Glantz, D. (2009). Vosstavshiie iz pepla [Colossus Reborn: The Red Army at War, 1941-1943]. Moskva: Yauza, Eksmo [in Russian].

Gorodetskii, G. (1995). Mif Ledokola. Nakanune voiny. Moskva: Progress, Akademiia [in Russian].

Goth, H., \& Guderian, H. W. (1999). Tankovyie operatsii. “Tanki-vpered”. Smolensk: Rusich [in Russian].

Halder, F. (2004). Voiennyi dnevnik. 22.06.1941-24.09.1942. Moskva: Olma-Press [in Russian].

Hastings, M. (2019). І розверзлося пекло... Світ у війні 1939-1945 років / I rozverzlosia peklo... Svit u viini 1939-1945 rokiv [All Hell Let Loose: The World at War 1939-1945]. Kharkiv: Klub Simeinoho dozvillia [in Ukrainian].

Hawes, J. (2000). Kratkaia istoriia Germanii [The Shortest History of Germany]. Moskva: Azbuka-Attikus [in Russian].

Heinz, H. (2004). SS i orden «Mertvaia golova». Moskva: Tsentrpoligraf [in Russian].

Helger G., \& Mejer A. (2008). Rossiia i Germaniia. Soiuzniki ili vragi? M.: ZAO “Tsentrpoligraf” [in Russian].

Jakobsen, G. (2005). Vtoraia mirovaia voina. Vzgliad iz Germanii. Moskva: Yauza, Eksmo [in Russian].

Levitas, F. (2002). Napad natsystskoi Nimechchyny na SRSR ochyma heneraliv Vermakhtu. Storinky voiennoi istorii Ukrainy, 6, 96-99 [in Ukrainian].

Levitas, F. (2012). Druha svitova viina: ukrainskyi vymir. Kyiv: Nash chas [in Ukrainian].

Meltuhov, M. (2000). Upushchennyi shans Stalina. Moskva: Veche [in Russian].

Mitcham, S. W. Jr., \& Mueller, G. (1995). Komandiry Tretiego Reikha [Hitler's Commanders]. Smolensk: Rusich [in Russian].

Mukovskyi, I., \& Lysenko, O. (1996). Zvytiaha i zhertovnist. Ukraina na frontakh Druhoi svitovoi viiny. Kyiv: Knyha pamiati Ukrainy [in Ukrainian].

Pleshakov, K. (2006). Oshibka Stalina. Pervyie 10 dnei voiny. M.: Eksmo [in Russian].

Popovych, M. (2005). Chervone stolittia. Kyiv: ArTek [in Ukrainian].

Rudoi, G. (Comp.). (2000). Otkroveniia i priznaniia. Natsistskaia verkhushka o voine "Tretiego Reikha» protiv SSSR. Sekretnyie rechi. Dnevniki. Vospominaniia. Smolensk: Rusich [in Russian].

Runov, V. (2011). Udar po Ukraine. Vermakht protiv Krasnoi Armii. Moskva: Veche [in Russian].

Runov, V. (2010). Pobednyi parad Gitlera. Pravda ob Umanskom poboishche. Moskva: Yauza, Eksmo, 416 p. [in Russian].

Sharipov, A. (1978). Cherniakhovskii. Moskva: Molodaia gvardiia [in Russian].

Solovev, I., \& Chugunov, A. (Comps.). (1976). Pogranichnye voiska SSSR v Velikoi Otechestvennoi voine. 1941: sbornik dokumentov i materialov. Moskva: Nauka. [in Russian].

Tippelskirch, K., Kesselring, A., \& Guderian, H. W. et. al. (1998). Itogi Vtoroi mirovoi voiny. Vyvody pobezhdennykh. Moskva: Poligon, AST [in Russian].

Vaniukov, D., \& Gnusakov, A. (2007). Velikaia Otechestvennaia voina. Moskva: Mir knigi [in Russian].

Westphal, S., Kreipe, W., Blumentrit, G., Bayeriein, F., Zeitzler, K., Zimmerman, B., \& Manteuffel, H. von (1999). Rokovyie resheniia Vermakhta [The Fatal Decisions]. Rostov na Donu: Feniks [in Russian].

Yekelchyk, S. (2020). Ukrainskyi dosvid Druhoi svitovoi viiny. Kyiv: Meduza [in Ukrainian].

Дата надходження статmі до редакції: 14.09.2021.

Creative Commons Licenses: Attribution-NonCommercial-ShareAlike 4.0 International (CC BY-NC-SA 4.0) 